\title{
Pola Komunikasi Interpersonal Guru Dan Murid dalam Pembinaan Akhlak di SMP Plus Nurul Hikmah Pamekasan
}

\author{
Anna Rofiatun', Siti Mariyam² \\ ${ }^{1,2)}$ Institut Agama Islam Negeri Madura \\ annarofiatun08@gmail.com
}

\begin{abstract}
Interpersonal communication in schools that is established between teacher and student is one important factor in determining individual development, especially the development of morals. Each teacher, of course, has a way to educate and nurture in different ways. The purpose of this study is to describe the patterns of interpersonal communication carried out by teachers and students in fostering morals at SMP Plus Nurul Hikmah Pamekasan. The purpose of this study is to describe the patterns of interpersonal communication carried out by teachers to students in moral development in Nurul Hikmah Pamekasan Middle School and describe the relationship between teachers and students after the application of interpersonal communication patterns in SMP Plus Nurul Hikmah Pamekasan. This study uses a qualitative approach to the type of case study descriptive research. Data sources obtained through interviews and observations with teacher and student informants. While checking the validity of the data is done through the perseverance of researchers and triangulation. The results of research conducted at SMP Plus Nurul Hikmah Pamekasan show that interpersonal communication between teacher and student in the process of moral formation goes quite well. This is evidenced in terms of the communication approach that is carried out by motivating and fostering students to become people of moral mercy. The relationship that exists between teacher and student can be felt after the application of interpersonal communication patterns. This is evidenced by the closeness between the teacher (communicator) and students (communicant) after communication between the two parties occurs, there is a problem resolution and a change in attitude to students. While the changes felt by students after the application of interpersonal communication is done, there is a fear of making mistakes and changing attitudes to be better than before. So that the interpersonal communication patterns of teachers and students in moral development in SMP Plus Nurul Hikmah Pamekasan are declared successful.
\end{abstract}

Keywords: Interpersonal Communication, Teachers and Students, Morals

\section{Abstrak}

Komunikasi interpersonal di sekolah yang terjalin antara guru dan murid merupakan salah satu faktor penting dalam menentukan perkembangan individu terutama perkembangan akhlak. Setiap guru, tentunya memiliki cara mendidik dan mengasuh dengan cara yang berbeda-beda. Tujuan Penelitian ini adalah untuk mendeskripsikan pola komunikasi interpersonal yang dilakukan oleh guru dan murid dalam membina akhlak di SMP Plus Nurul Hikmah Pamekasan. Tujuan penelitian ini untuk 
mendeskripsikan pola komunikasi interpersonal yang dilakukan oleh guru kepada murid dalam pembinaan akhlak di SMP Plus Nurul Hikmah Pamekasan dan mendeskripsikan hubungan antara guru dan murid setelah penerapan pola komunikasi interpersonal di SMP Plus Nurul Hikmah Pamekasan. Penelitian ini menggunakan pendekatan kualitatif dengan jenis penelitian deskriptif studi kasus. Sumber data yang diperoleh melalui wawancara dan observasi dengan informan guru dan murid. Sedangkan pengecekan keabsahan data dilakukan melalui ketekunan peneliti dan triangulasi. Hasil penelitian yang dilakukan di SMP Plus Nurul Hikmah Pamekasan menunjukan bahwa komunikasi interpersonal antara guru dan murid dalam proses pembentukan akhlak berjalan dengan cukup baik. Hal ini dibuktikan dari segi pendekatan komunikasi yang dilakukan yaitu dengan memotivasi dan membina murid untuk menjadi orang yang berakhlakul karimah. Hubungan yang terjalin antara guru dan murid yang bisa dirasakan setelah penerapan pola komunikasi interpersonal. Hal tersebut dibuktikan dengan kedekatan antara guru (komunikator) dan murid (komunikan) setelah komunikasi antara kedua belah pihak terjadi, ada penyelesaian masalah dan perubahan sikap pada murid. Sedangkan perubahan yang dirasakan oleh murid setelah penerapan komunikasi interpersonal dilakukan yaitu ada ketakutan untuk melakukan kesalahan dan mengubah sikap untuk menjadi lebih baik dari sebelumnya. Sehingga pola komunikasi interpersonal guru dan murid dalam pembinaan akhlak di SMP Plus Nurul Hikmah Pamekasan dinyatakan berhasil.

Kata Kunci: Komunikasi Interpersonal, Guru dan Murid, Akhlak

\section{Pendahuluan}

\section{Konteks Penelitian}

Perkembangan hubungan manusia dewasa ini memberikan dampak pada cara manusia berkomunikasi. Hal tersebut disebabkan kedekatan seseorang dengan orang lain bukan hanya dilihat dari pesan yang disampaikan tetapi juga dari proses dan cara berkomunikasi yang diterapkan pada setiap individu. Komunikasi merupakan kebutuhan setiap manusia dalam mempertahankan kelangsungan hidupnya, bahkan hampir tidak mungkin jika ada seseorang yang dapat menjalani hidupnya tanpa berkomunikasi dengan orang lain.

Dalam ruang lingkup yang lebih rinci, komunikasi menggambarkan seseorang yang menyampaikan sesuatu lewat bahasa atau simbol tertentu kepada orang lain. Dalam proses komunikasi, kewajiban komunikator adalah mengusahakan agar pesan-pesannya dapat diterima oleh komunikan sesuai dengan kehendak pengirim. Model proses komunikasi secara umum dapat memberikan gambaran kepada pengelola organisasi, cara memengaruhi atau mengubah sikap anggotanya melalui desain dan implementasi komunikasi.

Komunikasi tidak akan bisa berlangsung tanpa didukung oleh unsur-unsur komunikasi, seperti pengirim, pesan, saluran, penerima, dan akibat/pengaruh. Unsur-unsur inilah yang menjadi tolak ukur berhasil atau tidaknya proses komunikasi. Pada dasarnya pola komunikasi mempunyai empat macam tipe: pertama, komunikasi intrapersonal (diri sendiri); kedua, komunikasi interpersonal (antarpribadi); ketiga, komunikasi publik atau bisa disebut dengan komunikasi kelompok; dan keempat, komunikasi massa. Terdapat perbedaan antara komunikasi 
massa dan komunikasi antarpribadi. Komunikasi massa memakai saluran-saluran media massa, sedangkan komunikasi antarpribadi menggunakan saluran-saluran yang bersifat pribadi.

Komunikasi interpersonal atau disebut dengan komunikasi antarpribadi yaitu proses komunikasi yang berlangsung antara dua orang atau lebih secara tatap muka, seperti yang dinyatakan oleh R. Wayne Pace bahwa "interpersonal communication is communication involving two or more people in a face to face setting." Pada hubungan komunikasi interpersonal ini, komunikator membuat prediksi terhadap satu sama lain atas dasar data psikologis. Masing-masing mencoba mengerti pihak lainnya dengan bertindak sebagai individu.

Dalam situasi komunikasi interpersonal komunikator memiliki banyak informasi mengenai keinginan, kebutuhan, dan nilai-nilai pribadi satu sama lain serta dapat mengembangkan gaya komunikasi yang cocok bagi kedua belah pihak. Dari beberapa definisi di atas dapat disimpulkan bahwa komunikasi antarpribadi merupakan komunikasi yang dilakukan secara tatap muka mengenai suatu hal yang dibicarakan dengan harapan adanya respond dan reaksi terhadap isi pesan yang mereka komunikasikan.

Perlu disadari bahwa komunikasi interpersonal pasti dibutuhkan dalam kehidupan sosial, bahkan pada proses belajar mengajar. Karena proses belajar mengajar pada hakikatnya adalah proses komunikasi, yaitu proses penyampaian pesan dari sumber pesan (guru) melalui saluran atau media tertentu ke penerima pesan (murid). Seperti komunikasi interpersonal yang diterapkan di salah satu lembaga di kota Pamekasan yaitu SMP Plus Nurul Hikmah Pamekasan. Guru dan murid di lembaga tersebut turut berperan aktif melakukan komunikasi interpersonal dalam kegiatan belajar mengajar maupun tidak.

Alasan peneliti memilih SMP Nurul Hikmah Pamekasan, sebab lembaga ini dikenal oleh masyarakat sebagai lembaga yang memberikan suasana belajar yang islami untuk menanamkan karakter dan akhlak islam kepada murid-muridnya. Selain itu, lembaga ini juga dikenal dengan berbagai prestasi yang dicapai. Oleh karena itu peneliti ingin mengetahui pola komunikasi yang dilakukan oleh guru dalam membina akhlak di lembaga tersebut sehingga bisa membentuk peserta didik yang berprestasi dan berakhlakul karimah.

SMP Plus Nurul hikmah merupakan sebuah lembaga pendidikan Islam yang berdiri sejak 30 Juni 2009. Lembaga ini berdiri karena adanya kekhawatiran yang luar biasa dari masyarakat mengenai degradasi moral anak remaja. Oleh karena itu, SMP Plus Nurul Hikmah mempunyai peran penting dalam membentuk pribadi yang baik dan berakhlakul karimah dalam mendidik murid-muridnya. Berdasarkan data yang diperoleh di tahun ajaan 2018/2019, saat ini SMP Nurul Hikmah mempunyai 35 tenaga pengajar dan 343 murid yang aktif dalam proses belajar mengajar.

Prinsip SMP Plus Nurul Hikmah tidak hanya mendidik murid ketika berada di dalam kelas, karena pada dasarnya seorang guru adalah orang yang bertanggung jawab untuk mendidik murid-muridnya di dalam maupun di luar sekolah, dan mendidik bukan hanya sekedar menyampaikan materi dan menuntut untuk 
memahaminya, tetapi seorang guru juga bertanggung jawab sebagai pendidik membentuk kepribadian yang berakhlakul karimah. Jika murid melakukan kesalahan atau pelanggaran yang merugikan dirinya maupun orang lain, maka guru tidak segan-segan memberikan teguran dan hukuman sesuai dengan pelanggaran yang dilakukan oleh murid.

Berdasarkan data yang diperoleh dari guru BK (Bimbingan Konseling) pada tahun ajaran 2018/2019, kurang lebih terdapat 20 murid yang tercatat sebagai murid yang memiliki akhlak yang kurang baik. Namun tidak menutup kemungkinan jumlahnya akan berubah karena pada dasarnya remaja mempunyai tingkat emosi yang belum terkontrol dengan baik. Kategori kenakalan murid di SMP Nurul Hikmah Pamekasan pada umumnya yaitu melanggar peraturan sekolah, konflik antar murid.

Hal tersebut disebabkan oleh beberapa faktor seperti kurangnya perhatian dari kedua orang tua, pergaulan dengan lingkungan yang kurang baik dan tidak menutup kemungkinan hal tersebut juga disebabkan oleh komunikasi yang kurang antara guru dan murid. Dalam hal ini, BK (Bimbingan Konseling) bertugas untuk memberikan layanan kepada murid di SMP Plus Nurul Hikmah seperti layanan orientasi, layanan bimbingan belajar, layanan informasi, dan layanan bimbingan dan konseling.

Pola komunikasi interpersonal yang baik dalam membentuk kepribadian murid yaitu guru sebagai komunikator harus mengawasi dan mengendalikan muridmuridnya dengan baik, sehingga akan terbentuklah karakteristik murid yang baik. Sebaliknya pola komunikasi yang salah dilakukan oleh guru akan menjadikan murid mudah terjerumus pada hal- hal negatif karena pada hakikatnya guru mempunyai peran yang penting dalam pengembangan akhlak murid-muridnya.

Guru merupakan orang pertama yang mencerdaskan manusia, orang yang memberi bekal ilmu pengetahuan, pengalaman, dan menanamkan nilai-nilai, budaya dan agama terhadap muridnya. Dalam proses pendidikan, guru berperan penting setelah orang tua dan keluarga. Di lembaga pendidikan, guru menjadi orang pertama yang bertugas dalam membimbing mengajar dan melatih muridnya mencapai kedewasaan. 


\section{Metode Penelitian}

\section{Pendekatan dan Jenis Penelitian}

Penelitian ini menggunakan pendekatan kualitatif. Penelitian kualitatif didefinisikan sebagai metode penelitian ilmu-ilmu sosial yang mengumpulkan dan menganalisis data berupa kata-kata (lisan maupun tulisan) dan perbuatan-perbuatan manusia serta peneliti tidak berusaha menghitung atau mengkuantifikasikan angkaangka.

Penelitian ini menggunkan jenis penelitian deskriptif. Dalam hal ini peneliti merumuskan suatu masalah yang memandu penelitian untuk mengeksplorasi atau memotret situasi sosial yang akan diteliti secara menyeluruh, luas dan mendalam. Metode ini bertujuan untuk melukiskan secara sistematis fakta atau karakteristik populasi tertentu atau bidang tertentu secara faktual dan cermat dan tidak mencari atau menjelaskan hubungan, tidak menguji hipotesis atau membuat prediksi. Dalam proses pengumpulan datanya, peneliti lebih menitikberatkan pada observasi lapangan dan suasana alamiah, dengan mangamati gejala-gejala, mecatat, mengateorikan, dan sedapat mungkin menghindari pengaruh kehadirannya untuk menjaga keaslian gejala yang diamati.

\section{Lokasi Penelitian}

Untuk menjamin penelitian ini terlaksana sesuai dengan harapan, maka diperlukan suatu ruang lingkup lokasi penelitian yang bertujuan benar-benar mengarah kepada objek yang diteliti. Lokasi penelitian ini akan dilaksanakan di SMP Plus Nurul Hikmah Jl. Jokotole Indah Blok C Kav. 4 Pamekasan. Alasan peneliti memilih penelitian ini karena melihat dari ekspektasi masyarakat, jika anakanaknya sekolah di SMP Plus Nurul Hikmah sudah pasti mereka terdidik dengan akhlak yang baik. Hal ini membuat peneliti tertarik untuk meneliti kebenaran yang terjadi di lapangan. Oleh karena itu peneliti ingin mengkaji lebih dalam lagi bagaimana pola komunikasi interpersonal yang dibangun oleh guru dan murid dalam pembentukan akhlak di SMP Plus Nurul Hikmah. Peneliti juga akan melihat respon/feedback dari komunikasi yang dilakukan oleh guru kepada muridmuridnya.

\section{Sumber Data}

Sumber data yang digunakan oleh peneliti dalam penelitian ini antara lain sebagai berikut:

1. Data Primer

Data Primer yaitu data yang diperoleh langsung dari narasumber melalui tahap wawancara dan merupakan informan utama yang secara langsung berkaitan dengan pokok permasalahan penelitian. Informan yang dipilih oleh peneliti terdiri dari beberapa guru dan murid yang berada di SMP Plus Nurul Hikmah. Peneliti berharap dengan pengumpulan data primer ini dapat membantu mendapatkan data mengenai masalah yang sedang diteliti. 


\section{Data Sekunder}

Data Sekunder yaitu data yang diperoleh atau dikumpulkan peneliti dari berbagai sumber yang telah ada. Data sekunder dapat diperoleh dari berbagai sumber seperti catatan sekolah, buku dan jurnal.

\section{Pengecekan Keabsahan Data}

Dalam penelitian keabsahan data dapat diukur dari adanya wawancara dengan narasumber yang dalam hal ini sudah ada kesepakatan sebelumnya tentang data yang dibutuhkan. Peneliti juga melakukan observasi dengan terjun langsung ke lapangan mengamati kegiatan pembinaan akhlak yang dilakukan di sekolah tersebut.

Untuk mengetahui apakah data yang diperoleh valid dan bisa dipertanggungjawabkan, maka peneliti berusaha mengeceknya agar mendapatkan hasil yang memuaskan. Dalam mengukur validitas data temuan digunakan teknis sebagai berikut:

1. Ketekunan Peneliti

Ketekunan peneliti yaitu untuk menemukan ciri-ciri atau unsur- unsur dalam situasi yang sesuai dengan permasalahan yang sedang diamati. Terkait dengan topik dan persoalan disekitar permasalahan yang menjadi obyek dari peneliti, hal tersebut dilakukan secara bertahap, perincian, serta mengamati secara seksama.

2. Trianggulasi

Trianggulasi adalah pemeriksaan keabsahan temuan-temuan dengan memanfaatkan sesuatu yang lain untuk pengecekan atau perbandingan data. Dalam hal ini peneliti menggunakan dua metode triangulasi, yaitu:

a. Triangulasi sumber, yaitu menggali kebenaran informai tertentu melalui berbagai metode dan sumber perolehan data. Misalnya, selain melalui wawancara dan observasi, peneliti bisa menggunakan dokumen tertulis, dokumen sejarah, catatan resmi, catatan atau tulisan pribadi dan gambar atau foto. Masing-masing cara itu akan menghasilkan bukti atau data yang berbeda, yang selanjutnya akan memberikan pandangan (insights) yang berbeda pula mengenai fenomena yang diteliti.

b. Triangulasi metode, yaitu dilakukan dengan cara membandingkan informasi atau data dengan cara yang berbeda. Dalam penelitian kualitatif peneliti menggunakan metode wawancara, obervasi, dan survei. Untuk memperoleh kebenaran informasi yang handal dan gambaran yang utuh mengenai informasi tertentu, peneliti bisa menggunakan metode wawancara dan obervasi atau pengamatan untuk mengecek kebenarannya. Selain itu, peneliti juga bisa menggunakan informan yang berbeda untuk mengecek kebenaran informasi tersebut. Triangulasi tahap ini dilakukan jika data atau informasi yang diperoleh dari subjek atau informan penelitian diragukan kebenarannya. 


\section{Pembahasan}

\section{Pola komunikasi interpersonal yang dilakukan oleh guru dalam pembinaan akhlak murid di SMP Plus Nurul Hikmah Pamekasan}

Komunikasi sangat berperan dalam kehidupan sehari-hari, salah satunya ketika berada di sekolah. Karena dalam proses kegiatan belajar mengajar dan mendidik murid terdapat unsur yang saling mempengaruhi komunikasi yang dilangsungkan dengan sadar dengan keinginan untuk mengetahui dan mempengaruhi. Dengan komunikasi, proses perubahan tingkah laku akan terjadi dari tidak mengerti menjadi mengerti dan yang awalnya tidak tahu menjadi tahu. Dengan demikian komunikasi dapat menimbulkan efek sesuai dengan tujuan yang diharapkan, yaitu mendidik dan memperbaiki akhlak murid sehingga bisa melahirkan murid yang berakhlakul karimah.

Dalam al-Qur'an akan ditemukan contoh konkret Allah selalu komunikasi dengan hambaNya melalui wahyu. Untuk menghindari kesalahan dalam menerima pesan melalui ayat-ayat tersebut, Rasulullah untuk meredaksi wahyu-Nya melalui muatan hadits. Baik hadis itu bersifat qawliyah (perkataan), fi 'liyah (perbuatan), dan taqrîr (persetujuan) Rasul, kemudian ditambah lagi dengan lahirnya para ahli tafsir. al-Qur'an menjelaskan cara berbicara yang efektif, sebagaimana firman Allah dalam QS an-Nisa ayat 63: Artinya: "Mereka itu adalah orang-orang yang Allah mengetahui apa yang di dalam hati mereka. Karena itu berpalinglah kamu dari mereka, dan berilah mereka pelajaran, dan katakanlah kepada mereka perkataan yang berbekas pada jiwa mereka."

Dalam hal ini terkait dengan akhlak murid, motivasi murid untuk menjadi pribadi yang lebih baik dari sebelumnya tidak lepas dari adanya peranan penting seorang guru yang mampu memotivasi dan mendidik murid ke arah yang lebih baik. Tidak bisa dipungkiri lagi bahwasannya peranan komunikasi interpersonal guru sangat penting untuk memotivasi muridnya. Hal tersebut dikarenakan komunikasi merupakan sebuah hal yang sangat penting dalam dunia pendidikan.

Salah satu tujuan komunikasi interpersonal adalah proses penyampaian suatu pesan oleh seseorang kepada orang lain untuk memberitahu atau mengubah sikap, pendapat atau perilaku baik secara langsung maupun tidak langsung. Dalam prinsip komunikasi, ketika pihak komunikan menerima pesan atau informasi, berarti komunikan telah mendapat pengaruh dari proses komunikasi. Sebab pada dasarnya, komunikasi adalah sebuah fenomena, sebuah pengalaman. Setiap pengalaman akan memberi makna pada situasi kehidupan manusia, termasuk memberi makna tertentu terhadap kemungkinan terjadinya perubahan sikap.

Berdasarkan temuan penelitian tentang komunikasi interpersonal yang dilakukan oleh guru kepada murid di SMP Plus Nurul Hikmah. Menunjukkan bahwa guru sebagai komunikator sudah melaksanakan tugasnya dengan cukup baik dalam mendidik murid. Seperti melakukan pendekatan terlebih dahulu dengan mengetahui karakteristik murid terlebih dahulu sebelum berkomunikasi dengan murid. Berdasarkan pendekatan konteks, komunikasi interpersonal berlangsung saat beberapa orang yang memiliki kedekatan secara fisik berkomunikasi dengan 
menggunakan semua indranya, dan bisa langsung menyampaikan umpan baliknya. Sedangkan pada perspektif proses, komunikasi interpersonal dipandang sebagai proses pertukaran makna di antara orang-orang yang berkomunikasi.

Dalam melakukan suatu komunikasi kepada komunikan yang harus diperhatikan adalah bagaimana komunikasi tersebut dapat dimengerti oleh komunikan atau mengerti dengan apa yang bicarakan oleh komunikator. Dalam hal ini yang dimaksud dengan pendekatan adalah metode dan cara yang digunakan komunikator dalam berkomunikasi sehingga menghasilkan efek atau umpan balik. Berikut pendekatan dalam komunikasi interpersonal yang terbagi menjadi 2 macam pendekatan yakni pendekatan fungsional dan pendekatan situsional.

a. Pendekatan Fungsional

Prinsip-prinsip pendekatan fungsional terhadap konteks komunikasi bersumber dari studi sosiologi dan antropologi, sehingga sering pendekatan ini disebut dengan pendekatan sosiologi-antropologis. Pendekatan ini berasumsi bahwa setiap anggota masyarakat memiliki kebutuhan tertentu dan untuk mempertemukan kebutuhan-kebutuhan ini, maka masyarakat menyediakan beberapa lembagayang berperan mengelola interaksi diantara mereka. Pendekatan fungsional merupakan salah satu pendekatan yang di gunakan dalam komunikasi interpersonal dengan melihat pada fungsi atau peran dari suatu lembaga misalnya lembaga pendidikan seperti sekolah yang berperan fungsinya sebagai tempat untuk mendapatkan pelajaran dan menuntut ilmu karena jika disesuaikan dengan kebutuhan masyarakat dan terpenuhi.

b. Pendekatan Situsional

Pendekatan ini diambil dengan "What is situsional awareness?" Atau apakah yang di maksud dengan "kesadaran situasi itu?" kesadaran situsional adalah kesadaran manusia tentang lingkungan pada suatu saat, misalnya saat sekarang yang membuatnya mampu mengantisipasi secara akurat masalah masa depan dan pada gilirannya mendorong untuk mengaktifkan tindakan contohnya (komunikasi) yang efektif. Pendekatan situsional ini dimulai dengan kesadaran individu sebagai dasar untuk melacak dan mencatat sumber dari akibat informasi tentang karakteristik lingkungan serta mencari dan menemukan komuikasi untuk membuat keputusan, sebagai tindakan komunikasi yang komunikatif dan informatif.

Pada kegiatan komunikasi interpersonal yang dilakukan oleh guru SMP Plus Nurul Hikmah ini berlangsung dalam proses bentuk interaksi dan interrelasi yang mendorong terjadinya perubahan dan tindakan yang terus- menerus. Masingmasing pihak yang berkomunikasi akan terus saling menyesuaikan. Selain itu, terjadi pertukaran pesan dan makna selama proses komunikasi berjalan, dan dalam pesan tersebut terkadung makna yang membuat komunikasi menghasilkan kesamaan pemahaman.

Secara sederhana proses komunikasi interpersonal akan berjalan lancar apabila adanya pengirim atau komunikator yang menyampaikan informasi berupa lambang verbal maupun nonverbal kepada penerima atau komunikan dengan menggunakan media suara atau tulisan. Dalam hal ini proses komunikasi interpersonal mempunyai komponen-komponen yang saling berkaitan yaitu: a) 
Sumber (Komunikator); b) Encoding; c) Pesan; d) Saluran; e) Penerima (Komunikan); f) Decoding; g) Respon; h) Gangguan; dan i) Konteks Komunikasi.

Keberhasilan komunikasi harus didukung oleh keberhasilan komunikator menyampaikan pesan, cara penyampaian pesan, isi pesan, penerimaan komunikan menerima pesan dan mengirim pesan kembali kepada komunikator. Penggunaan komunikasi yang tepat sangat berpengaruh terhadap pemahaman dari murid itu sendiri. Dikarenakan dalam hal ini seorang guru sebagai komunikator yang memberikan segala informasi yang berhubungan dengan berbagai ilmu pengetahuan dan akhlak. Oleh karena itu diperlukan kecakapan dalam hal berkomunikasi agar murid dapat dengan cepat memahami apa yang disampaikan oleh guru tersebut.

Hasil temuan penelitian menunjukkan bahwa guru tidak lupa selalu membeberikan ilmu tentang pentingnya akhlak baik itu ketika kegiatan belajar mengajar maupun tidak, karena akhlak merupakan salah satu komponen yang paling penting untuk dimiliki oleh manusia. Secara umum, hampir semua lembaga pendidikan atau sekolah memiliki visi dan misi yang mendukung terwujudnya kultur akhlak yang mulia. Visi dan misi sekolah merupakan cita- cita sekaligus menjadi arah yang akan dicapai oleh sekolah dalam jangka waktu tertentu.

Dengan menetapkan pengembangan kultur akhlak mulia dalam visi atau misi sekolah, maka sekolah memiliki tekad dan semangat yang kuat untuk mewujudkannya dalam waktu yang sudah direncanakan. Dengan demikian, sekolah sudah selayaknya melakukan beberapa upaya untuk mewujudkan cita-cita tersebut, baik melalui tata tertib sekolah atau program- program sekolah dan juga melalui pembiasaan nilai-nilai akhlak mulia dalam kehidupan sehari-hari di sekolah baik yang terkait dengan pembiasaan keagamaan maupun pembiasaan nilai-nilai kebaikan yang umum.

Akhlak mulia di lingkungan sekolah, harus tercermin dalam praktik kehidupan sehari-hari semua warga sekolah yang meliputi guru, murid, dan kepala sekolah. Semua komponen sekolah, harus menghiasi dirinya dengan akhlak yang mulia, seperti berlaku jujur, amanah, tanggung jawab, rasa hormat, peduli, santun, lapang dada, toleran, tekun dan sabar. Dengan menanamkan dan mempraktikkan sikap dan perilaku tersebut, maka pada waktunya kelak akan terbangun kultur akhlak mulia ketika berada di lingkungan sekolah maupun di luar sekolah.

Dalam melakukan kegiatan komunikasi dengan murid pastinya guru akan megalami kesulitan, kesulitan itu jelas menghambat proses komunikasi yang dilakukan guru dalam mengatasi masalah yang dialami oleh murid di SMP Plus Nurul Hikmah Pamekasan terutama permasalahan tentang akhlak. Guru mengalami kesulitan berkomunikasi dengan murid ketika murid yang dihadapi mempunyai kontrol emosi yang kurang baik sehingga pesan yang disampaikan guru tidak diterima dengan baik oleh murid membuat feedback yang diberikan murid tidak sesuai dengan yang diharapkan oleh guru sehingga membuat komunikasi tidak efektif. Guru juga mengalami kesulitan ketika terdapat noise atau gangguan sehingga membuat pesan atau informasi yang disampaikan oleh guru tidak berjalan dengan baik. Sehingga guru harus mengulangi kembali pesan yang ingin 
disampaikan dan membuat komunikasi tidak efektif.

Jika murid masih saja memiliki akhlak yang kurang baik, atau guru belum berhasil dalam membina akhlaknya. Maka seorang guru harus melakukan sebuah pendekatan persuasif. Pendekatan persuasif bertujuan untuk mengubah atau memengaruhi kepercayaan, sikap, dan perilaku seseorang sehingga bertindak sesuai dengan apa yang diharapkan oleh guru (komunikator). Salah satunya dengan pelaksanaan pemberian bantuan oleh guru bimbingan konseling kepada siswa-siswi yang akhlaknya kurang baik memerlukan banyak waktu, proses continue serta sistematis dan memerlukan pengamatan. Selaku guru pembimbing adalah seorang pendidik atau pengajar yang bertanggung jawab membimbing pada siswa agar terbentuk akhlak yang kurang baik menjadi baik. Dasar keagamaan perlu ditanamkan dalam membina siswa agar selalu ada perkembangan pembentukan akhlak siswa yang melakukan akhlak yang kurang baik menjadi baik dengan cara dibimbing oleh guru.

Menggunakan komunikasi interpersonal sangat ampuh dibanding bentuk komunikasi lainnya. Alasannya karena komunikasi berlangsung secara tatap muka oleh karena itu guru (komunikator) dengan komunikan saling bertatap muka, maka terjadilah kontak pribadi. Misalnya pribadi guru menyentuh pribadi muridnya. Dengan menggunakan metode bil hikmah, menasehati kekeliruan yang dialami murid dengan lemah lembut serta memberikan contoh yang baik kepada muridmuridnya. Seperti yang dijelaskan dalam surat an-Nahl ayat 125: Artinya:"Serulah (manusia) kepada jalan Tuhan-mu dengan hikmah dan pelajaran yang baik dan bantulah mereka dengan cara yang baik. Sesungguhnya Tuhanmu Dialah yang lebih mengetahui tentang siapa yang tersesat dari jalan- Nya dan Dialah yang lebih mengetahui orang-orang yang mendapat petunjuk."

Komunikasi yang dilakukan oleh guru SMP Plus Nurul Hikmah tidak hanya melalui komunikasi verbal, komunikasi nonverbal juga harus diterapkan karena jika guru hanya sekedar memberikan nasehat tanpa memberikan contoh yang baik maka pesan yang akan dituju kepada murid tidak akan tersampaikan dengan baik. Komunikasi verbal adalah komunikasi yang dilakukan dengan menggunakan katakata baik secara lisan mapun tulisan. Melalui kata-kata manusia mampu mengungkapkan perasaan, emosi, pemikiran, gagasan atau maksud, menyampaikan data dan informasi, serta saling bertukar perasaan dan pemikiran.

Sedangkan komunikasi nonverbal merupakan komuniakasi yang tidak disampaikan melalui kata-kata, berisi penekanan, pelengkap, bantahan, keteraturan, pengulangan atau pengganti pesan verbal, atau bentuk komunikasi yang menggunakan bahasa isyarat atau body language sebagai sarana untuk berkomunikasi dengan orang lain.

\section{Hubungan guru dan murid setelah penerapan pola komunikasi interpersonal di SMP Plus Nurul Hikmah Pamekasan}

Komunikasi interpersonal yang efektif dapat menunjukkan ada pemahaman yang sama atas pesan yang disampaikan pada saat komunikasi berlangsung antara 
komunikator dan komunikan. Perlu diketahui bahwa untuk melihat efektif tidaknya komunikasi interpersonal yang berlangsung, dapat dilihat dari umpan balik antara pemberi dan penerima pesan. Umpan balik dapat berupa pernyataan, sikap dan tindakan.

Terpenting dalam komunikasi interpersonal adalah bagaimana sepatutnya berkomunikasi dengan baik supaya proses pembentukan hubungan dalam mencapai tujuan dapat berjalan dengan baik dan memenuhi keperluan sermua pihak. Disamping itu komunikasi interpersonal juga dipengaruhi oleh faktor-faktor, yaitu: citra diri (self image) karena citra diri menentukan ekspresi dan persepsi orang. Kedua, citra pihak lain (the image of the others). Ketiga, lingkungan fisik mempunyai kaitan dengan faktor citra diri dan citra pihak lain. Keempat, lingkungan sosial mempengaruhi tingkah laku dan komunikasi. Kelima, kondisi fisik maupun emosional, dan keenam, bahasa tubuh karena komunikasi tidak hanya dikirim atau terkirim melalui kata-kata yang diucapkan.

Seorang guru (Komunikator) selaku komponen penggerak harus mampu melakukan komunikasi interpersonal dengan baik dan efektif sehingga dalam proses belajar mengajar maupun pembinaan akhlak oleh guru kepada murid akan terjadi peningkatan perilaku yang lebih baik pada murid. Maka, guru harus berkomunikasi dengan menggunakan bahasa yang mudah di mengerti oleh murid dan mampu dicermati tentang penjelasan-penjelasan yang di sampaikan kepada mereka.

Komunikasi yang efektif sangat diharapkan oleh semua orang dan terus berlangsung dalam interaksi dengan orang lain, akan tetapi dalam proses komunikasi tidak semuanya berjalan dengan baik sesuai dengan apa yang diharapkan. Usaha untuk berkomunikasi secara memadai terkadang megalami hambatan. Adapun faktor pendukung dan penghambat dalam penyampaian pesan yang dilakukan oleh guru kepada murid yang tentunya akan menyebabkan proses dalam berkomunikasi interpersonal tidak efektif. Secara umum penyebab terjadinya kegagalan-kegagalan dan menjadi faktor penghambat dalam komunikasi yaitu: a) Dilaksanakan dengan tergesa-gesa; b) Sewaktu pelaksanaan pikiran sedang kacau; c) Perasaan sedang terganggu; d) Kesehatan kurang baik; e) Berprasangka buruk; f) Kurang baik dalam berbahasa; g) Mau menang sendiri

Komunikasi akan mengalami kegagalan jika dilakukan dengan tergesagesa dan pikiran sedang kacau sehingga apa yang ada dalam pikiran dapat terganggu karena tidak fokus dengan apa yang disampaikan (karena kesehatan kurang baik atau dalam keadaan emosional) begitu juga jika komunikasi dilakukan dengan tergesa-gesa maka akan terjadi miss communication karena pesan yang disampaikan tidak jelas dan tidak sesuai dengan maksud dari pesan itu sendiri.

Adapun faktor pendukung komunikasi interpersonal sebagai berikut:

a. Mendengarkan komunikiasi harus dilakukan dengan pikiran dalam hati serta segenap indra yang di arahkan kepada si pendengar.

b. Pernyataan komunikasi pada hakekat kegiatan menyatakan sesuatu gagasan (isi hati dan pikiran) dan menerima umpan balik yang berarti menafsirkan 
pernyataan tentang gagasan orang lain.

c. Keterbukaan orang yang mau senantiasa tumbuh, sesuai dengan zaman adalah orang yang menerima masukan dari orang lain, merenungkan dengan serius, dan merubah diri bila perubahan dianggap sebagai pertumbuhan kearah kemajuan.

d. Kepekaan adalah kemahiran membaca bahasa badan, komunikasi yang tidak diungkap dengan kata-kata.

e. Umpan balik sebuah komunikasi baru bernama timbal balik, jika pesan yang dikirim berpantulan, yakni mendapatkan tanggapan yang dikirim kembali.

Faktor pendukung ini dapat dikatakan sebagai lawan faktor penghambat komunikasi interpersonal di atas. Maka dengan mendengarkan pernyataan komunikasi kita dapat mengetahui maksud dari isi pesan yang disampaikan dan dapat saling terbuka dalam memecahkan masalah dari pembahasan yang berlangsung serta peka terhadap bahasa nonverbal menjadi faktor pendukung dalam komunikasi interpersonal, dengan demikian akan menghasilkan umpan balik dan komunikasi dapat berjal;an secara efektif antara komunikator dengan komunikan.

Faktor pendukung dan penghambat dalam komunikasi dapat terjadi selama proses komunikasi berlangsung ataupun sebelum memulai komunikasi baik dilihat dari komunikator ataupun komunikan, maka dari itu saat melakukan komunikasi perlu memperhatikan situasi dan kondisi diri terlebih dahulu agar dapat terjadi efek setelah penyampaian komunikasi.

\section{Kesimpulan}

4. Komunikasi interpersonal guru dalam membina akhlak murid SMP Plus Nurul Hikmah Pamekasan dilakukan menggunakan komunikasi verbal dan non verbal, dengan membina secara lisan dan perbuatan yang baik agar dapat di contoh oleh murid merupakan salah satu penerapan cara membina akhlak oleh guru kepada murid. Guru sebagai komunikator di SMP Plus Nurul Hikmah Pamekasan sudah menjalankan perannya dengan baik dalam mendidik murid. Baik dari segi pendekatan komunikasi yang dilakukan, memotivasi dan membina murid untuk menjadi orang yang berakhlakul karimah.

5. Komunikasi interpersonal digunakan oleh guru dalam bentuk konseling dengan sikap komunikasi yang ramah dan bersifat konseling maupun terbuka pada murid menjadikan kemudahan guru dalam menyampaikan pesan dengan maksud dan tujuan yang baik sehingga murid dapat lebih mudah menerima pesan dan tertarik dengan kenyamanan dan keramahan. Adapun dampak yang bisa dirasakan setelah penerapan pola komunikasi interpersonal yang dilakukan oleh guru kepada murid. Hal tersebut dibuktikan dengan adanya kedekatan yang terjadi antara guru (komunikator) dan murid (komunikan) setelah 
terjadinya komunikasi antara kedua belah pihak, adanya penyelesaian masalah dan adanya perubahan sikap pada murid. Sedangkan dampak yang dirasakan oleh murid setelah penerapan komunikasi interpersonal yaitu ada ketakutan untuk melakukan kesalahan dan perubahan sikap menjadi lebih baik.

\section{Daftar Pustaka}

Basri, Hasan. Keluarga Sakinah. Yogyakarta: Pustaka Fajar, 1997

Basuki dan Miftahul Ulum. Pengantar Ilmu Pendidikan Islam. Ponorogo: Stain Press, 2007.

Budyatna, Muhammaddan Leila Mona Ganiem. Teori Komunikasi Antarpribadi. Jakarta: Kencana Prenada Media Group, 2012.

Cangara, Hafied. Pengantar Ilmu Komunikasi. Jakarta: PT Raja Grafindo Persada, 2006.

Curtis. Komunikasi Bisnis dan Profesional. Bandung: PT Remaja Rosdakarya, 2006

Departemen Agama RI, Al-Qur'an dan Terjemahnya. Jakarta: CV Swakarya, 1990.

Effendy, Onong Udjana. Ilmu Komunikasi, Teori dan Praktek. Bandung: Remaja Roesdakarya, 1990.

Hadi, Sutrisno. Metodelogi Research Jilid 2. Yogyakarta: Andy Offset, 2002. Hardjana, Agus M. Komunikasi Intrapersonal \& Interpersonal. Yogyakarta: Kanisus, 2003

Haryono, Rudy. Kamus Lengkap Praktis. Jakarta:Cipta Media.

Iriantara, Yosal. Komunikasi Pembelajaran. Bandung: PT Remaja Rosdakarya Kinanti, Putri Cahaya. Pola Komunikasi dan Hubungan Interpersonal Ibu Single Parent Dan Anaknya (Studi Kasus Pada Siswa Smp Negeri 7

Kotabumi). Universitas Lampung, 2016.

Lanundi, A.G. Komunikasi Meningkatkan Efektifitas Komunikasi Antar pribadi. Yogyakarta: Kanisius, 2001.

Liliweri, Alo. Komunikasi Antar pribadi. Bandung: PT Remaja Rosdakarya, 1996.

Liliweri, Alo. Komunikasi Serba Ada Serba Makna. Jakarta: Citra Aditya Bakti, 2011

Lunandi. Komunikasi Mengenai: Meningkatkan Efektivitas Komunikasi Antar Pribadi. Yogyakarta: Kanisius, 1994.

Mansur. Pendidikan Anak Usia Dini dalam Islam. Yogyakarta: Pustaka Pelajar, 2009.

Moleong, Lexi, J. Metode Penelitian Kualitatif. Bandung: PT. Remaja Rosdakarya, 
2005.

Muhammad. Teori Komunikasi Antarpribadi. Jakarta: Kencana Prenada Media Group, 2011.

Pratiwi, Nindi. Pola Komunikasi Interpersonal Guru Dengan Siswa Dalam Membentuk Kemandirian Siswa Sekolah Luar Biasa Pondok Kasih Medan. Universitas Medan Area, 2017.

Sadiah, Dewi. Metode Penelitian Dakwah. Bandung: PT Remaja Rosdakarya, 2015.

Sambas, Syukriadi. Sosiologi Komunikasi. Bandung: CV Pustaka Setia, 2015. Sari, Andhita. Komunikasi Antarpribadi. Yogyakarta: CV Budi Utama, 2012. Solichin, Mohammad Muchlis. Akhlak dan Tasawuf Dalam Wacana Kontemporer. Surabaya: Pena Salsabila, 2017.

Solichin, Mohammad Muchlis. Pendidikan Akhlak/Tasawuf. Yogyakarta: SUKAPress, 2012.

Sugiono, Metode Penelitian Kuantitatif Kualitatif dan R\&D. Bandung: Alfabeta, 2008.

Sugiono, Metode Penelitian Pendidikan. Bandung: Alfabeta, 2010. Sukmadinata, Nana Syaodih. Metode Penelitian Pendidikan. Bandung:

Remaja Rosdakarya, 2016.

Sunendar, Dadang. Kamus Besar Bahasa Indonesia Edisi Kelima. Jakarta: Badan Pengembangan dan Pembinaan Bahasa, Kemendikbud, 2016.

Wakhidah, Nafisatul. Komunikasi Interpersonal Antara Ustadz dan Santri Dalam Menanamkan Nilai-Nilai Akhlak Di Pondok Modern Babussalam Kebonsari Madiun. UIN Sunan Kalijaga Yogyakarta, 2007.

Wiryanto, Pengantar Ilmu Komunikasi. Jakarta: Grasindo, 2005.

Wiryanto. Teori Komunikasi Massa. Jakarta: PT Grasindo, 2000.

Zulaika, Rika. Pola Komunikasi Interpersonal Orang Tua dalam Membentuk

Kepribadian Anak di Kelurahan Perawang Kecamatan Tualang

Kabupaten Siak (Kajian Pola Komunikasi Interaksional). UIN Suska

Riau, 2010. 